\title{
AN EVALUATION OF TWO GUIDANCE PROGRAMMES TO PROMOTE BREAST-FEEDING
}
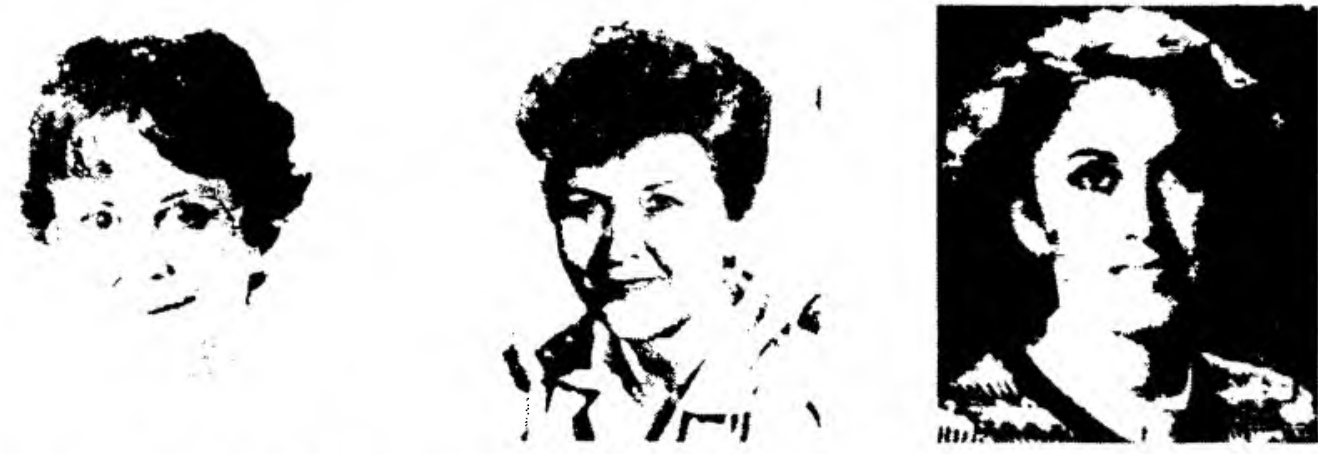

M. Steyn, A.S.P. Swanepoel, L.J. Rossouw, M.L. Langenhoven, P.L. Jooste

\section{Summary}

During the past ten years a comprehensive research project has been undertaken to develop a guidance programme in three adjacent communities in the South-Western Cape with the aim of lowering the high incidence of coronary heart disease.

The purpose of this substudy was to determine whether the guidance provided in the different communities had any influence on the knowledge of and attitudes towards the nutrition of pregnant women, babies and infants as well as breast-feeding practices of the women who gave birth during the period 1980 to 1986. In the first community guidance was provided by means of small mass media and interpersonal communication whereas only the small mass media were employed in the second. The third served as the control community.

The findings suggest that the combined interpersonal and mass media programme was more successful than the mass media programme alone.

\section{Opsomming}

Gedurende die afgelope tien jaar is 'n omvattende navorsingsprojek onderneem ten einde ' $n$ voorligtingsprogram in drie naasliggende gemeenskappe in Suidwes-Kaapland te ontwikkel met die doel om die hoë voorkoms van koronêre hartsiekte te verlaag.
Die doel met hierdie substudie was om te bepaal of die voorligtinginsette wat in die onderskeie gemeenskappe gemaak is, 'n effek gehad het op die kennis van en houdings oor voeding van die verwagtende vrou, baba-en kindervoeding asook op die borsvoedingsgebruike van vroue wat in die tydperk 1980 tot 1986 geboorte geskenk het. In die eerste gemeenskap is voorligting gedoen deur middel van klein massamedia en interpersoonlike kommunikasie, terwyl in die tweede area slegs die klein massamedia gebruik is. Die derde het as kontrole gedien.

Die bevindings dui daarop dat die gekombineerde interpersoonlike en massamediaprogram meer welslae as die massamediaprogram op sy eie bereik het.

\section{INTRODUCTION}

During the past ten years a comprehensive research project has been undertaken to develop a guidance programme in three adjacent communities in the SouthWestern Cape. The aim of the programme was to lower the high incidence of coronary heart disease by means of intervention regarding controllable risk factors. After a baseline study had been carried out in the three communities the guidance programme was tried out experimentally. In the first community, Robertson, guidance occurred in a combined mass and interpersonal programme. In the second community, Swellendam, only a mass media programme was launched, while in the third, Riversdale, no guidance was given.

A substudy of this project which is reported here, was aimed at pregnant women and mothers with babies in order to promote breast-feeding and to establish healthy eating habits at a very early age.

\section{AIM OF THE STUDY}

The main aim of this study was to determine whether the guidance concerning the nutritional needs of pregnant women, babies and children provided in the different areas during the period 1980 to 1986 had influenced the knowledge of and attitudes towards the nutrition of pregnant women, babies and infants as well as practices regarding breast-feeding of the women who had given birth during that period.

\section{NUTRITIONAL GUIDANCE}

\section{Pregnant women}

In both guidance areas (Robertson and Swellendam) guidance was given by means of literature that was mailed to the women concerned or given by the doctor or nurse as soon as pregnancy was confirmed. In Robertson the information was supplemented by individual or group counselling by the doctor, nurse and/or dietitian. Group counselling was based on two specific lesson plans - one for women who were two to five months pregnant and one for women who were more than five months pregnant. These sessions included information on the following: a general review of the role of nutrition during pregnancy with the emphasis on the normal growth of the fetus and a normal confinement; specific nutritional needs of the pregnant woman, including weight control; problems such as heartburn, nausea and constipation and possible solutions; motivation for breastfeeding; preparation and care of the breasts; the advantages of regular exercise 
and planned relaxation, and the disadvantages of smoking and the intake of alcohol during pregnancy.

\section{Mothers with babies}

The aim of the guidance to mothers with babies was to motivate them to breast-feed their babies for at least four months, to postpone the introduction of solids until the babies were three to four months old, and to control the babies' weight gain.

Recent information on the composition of mother's milk and its immunological characteristics reveals that mother's milk as the only source of nutrients for the young baby has significant advantages, even in modern, technologically developed communities (Brostrom 1981). Various world experts recommend that, if possible, breast-feeding should be continued for at least four to six months and that solids should not be introduced before the age of six months (Francis 1986; Byerley \& Kirksey 1985; Wharton 1982; Jelliffe \& Jelliffe 1979).

Research by Brogan and Fox (1984) revealed that attendance of guidance programmes motivated mothers to breastfeed their babies and to introduce solids at a later stage. According to the researchers one of the disadvantages of introducing solids too soon is infantile obesity. Glueck and Tsang (1979) regarded obesity as one of the important risk factors related to the development of atherosclerosis. Both the serum lipid levels of the adult and obesity are probably determined in part by a person's eating pattern and weight gain during childhood. The importance of establishing a healthy lifestyle is emphasized by the fact that the pathological mechanisms of atherosclerosis are present in children too. The development of good eating habits is one of the most important measures for preventing CHD (WHO report 1986).

\section{METHODS}

\section{Sample}

The sample was drawn by compiling a list of all women who had given birth in the three communities during the research period. In each of the communities a random sample was then drawn. The total realized sample consisted of 400 women.

\section{Questionnaire}

The data were collected by means of a pretested questionnaire containing questions on inter alia biographical factors, knowledge of and attitudes towards breast- and infant-feeding, participation in the programme, receipt of information and breast-feeding practices. Respondents completed the questionnaires after instruction by the researchers.

\section{Analysis of the data}

To establish the effects of the guidance programme on knowledge and attitudes the multiple regression technique was used, incorporating the variable "guidance" (mass media and interpersonal communication; mass media alone; no guidance). Other variables such as profession, age and educational level that might have had an effect on knowledge and attitudes were included to ensure that any guidance effect could be attributed solely to guidance. The logitmodel was used to establish which of the above predictors had an influence on breastfeeding.

\section{FINDINGS}

Although some of the other variables (e.g. age, educational level) show significant associations with attitudes, knowledge and breast-feeding, only the significant results in regard to the variable, guidance, will be reported here. To facilitate presentation of the data only associations between the dependant and independant variables which are significant at the $5 \%$-level are discussed here (details of the statistical analyses appear in Steyn et al. 1987).

\section{ATTITUDES}

A total of 16 items on attitudes were included in the questionnaire as follows: 10 on breast-feeding and 6 on feeding of infants. The respective items were answered on a five-point scale. A response of 5 indicated a strong positive attitude while a response of 1 indicated a strong negative attitude. A total score was determined for every respondent for each of the attitude fields. A higher total score indicated a more positive attitude while a lower score indicated a more negative attitude. Multiple regression analyses were then done to establish the effect of the guidance programme on the attitudes of the respondents.

\section{Attitudes towards breast-feeding}

These items were mainly concerned with the reasons why breast-feeding was necessary. The minimum and maximum total scores possible were 10 and 50 . The average score was 39,08 indicating that the respondents generally had fairly positive attitudes towards breast-feeding.

Results of the statistical analysis show a positive association between guidance and a positive attitude. Respondents in Robertson had a significantly higher average total score than in the other two communities from which can be deducted that they were generally more positively inclined towards breast-feeding.

\section{Attitudes towards infant-feeding}

These items dealt mainly with the eating patterns of infants and the ways in which eating problems can be solved by the mother. The minimum total score possible was 6 and the maximum 30 . The average score of 22,74 was relatively positive. Results of the multiple regression analysis once more show a positive association between guidance and the attitude scores - in general the respondents in Robertson were more positive than the respondents in the other two communities.

\section{KNOWLEDGE}

The 51 knowledge questions were divided as follows: pregnancy (21), breast-feeding (13) and nutrients (17). A score of 1 was allocated for each correct answer. A total score for each knowledge field was calculated before the multiple regression analysis technique was applied. A higher total score indicated a better knowledge of the subject.

Knowledge of nutrition during pregnancy These questions mainly concerned the pregnant woman's need of certain nutrients as well as weight control during pregnancy. The minimum total score possible was 0 and the maximum 21 . A relatively high average score of 15,22 was obtained. There was no significant association between guidance and knowledge.

\section{Knowledge of breast-feeding}

Thirteen questions were asked mainly about factors that could influence breastfeeding, the breast-fed baby's susceptibility to illness and the breast-feeding woman's susceptibility to mamma carcinoma. The minimum and maximum total scores possible were 0 and 13. An average score of 8,31 , which cannot be considered as high, was obtained. Statistical analysis shows a significant association between guidance and knowledge - respondents in Robertson generally scored higher than those in Swellendam and Riversdale.

\section{Knowledge of nutrients}

The seventeen questions in this field dealt inter alia with types of food which could complement the iron in a baby's diet as well as the components of milk and vitamin preparations. The minimum total score possible was 0 and the maximum 17 . A relatively low average total score of 8,81 was obtained. The results of the statistical analysis again show a positive association between guidance and knowledge. Respondents in Robertson achieved a higher average score than those in Swellendam and Riversdale.

\section{BREAST-FEEDING}

The respondents were asked whether they had breast-fed any of their babies born since 1980 , and if so what the duration of the breast-feeding was.

\section{First baby born since 1980}

Most of the respondents stated that they had breast-fed their first baby born since 1980:

$\begin{array}{ll}\text { Robertson } & 72 \% \\ \text { Swellendam } & 70 \% \\ \text { Riversdale } & 52 \%\end{array}$

Although the results of the logitmodel analysis show no significant association between guidance and breast-feeding these percentages suggest a greater trend for women in the experimental communities to breast-feed than women in the control area. 
As far as duration of breast-feeding of the first baby since 1980 was concerned relatively low percentages of respondents had breast-fed for longer than three months:

$\begin{array}{ll}\text { Robertson } & 41 \% \\ \text { Swellendam } & 28 \% \\ \text { Riversdale } & 28 \%\end{array}$

Statistical analysis shows no significant effect of guidance on duration of breastfeeding. However inspection of the percentages suggests a greater trend for breast-feeding for longer than three months in the combined mass media and interpersonal guidance area than in the other two communities.

\section{Second baby born since 1980}

As was the case with the first baby most of the respondents stated that they had breast-fed their second baby:

$\begin{array}{ll}\text { Robertson } & 76 \% \\ \text { Swellendam } & 63 \% \\ \text { Riversdale } & 59 \%\end{array}$

Again statistical analysis shows no significant association between guidance and breast-feeding. However according to the percentages there is an indication of a difference in trend especially between the combined mass media and interpersonal guidance community and the control area.

Breastfeeding for longer than three months of the second baby shows the following results:

$\begin{array}{ll}\text { Robertson } & 53 \% \\ \text { Swellendam } & 27 \% \\ \text { Riversdale } & 27 \%\end{array}$

A statistically significant association was found between guidance and duration of breast-feeding - proportionally more women in Robertson, the combined mass media and interpersonal guidance community had breast-fed their babies for longer than three months in the other two areas.

\section{One or more babies born since 1980} When the data concerning respondents who had given birth to one or more babies since 1980 and had breast-fed any one of these babies were inspected, the following results were found: in Robertson $76 \%$ of the respondents, in Swellendam $72 \%$ and in Riversdale $55 \%$ had breast-fed.

Statistical analysis shows a significant association between guidance and breastfeeding - proportionally more women in the two experimental communities respectively, had breast-fed their babies than in the control area.

\section{All babies born since 1980}

When the proportion of babies who were breast-fed are taken into account rather than the proportion of respondents who had breast-fed, it seems that approximately two-thirds of all babies had been breast-fed:

$\begin{array}{ll}\text { Robertson } & 74 \% \\ \text { Swellendam } & 68 \% \\ \text { Riversdale } & 55 \%\end{array}$

The results of the logitmodel analysis show a significant association between guidance and breast-feeding. Proportionally more babies in Robertson and in Swellendam than in Riversdale were breast-fed.

As far as the duration of breast-feeding is concerned the following percentages of babies were breast-fed for longer than three months.

$\begin{array}{ll}\text { Robertson } & 46 \% \\ \text { Swellendam } & 28 \% \\ \text { Riversdale } & 29 \%\end{array}$

Again the results of the logitmodel analysis show a significant association between guidance and duration of breastfeeding - proportionally more babies in Robertson than in Swellendam and Riversdale were breast-fed for three months or longer.

\section{CONCLUSION}

The effect of the guidance programmes can be seen clearly from the findings that the respondents from Robertson (mass media and interpersonal guidance) generally had more positive attitudes towards both attitude fields and that they fared significantly better in two of the three knowledge fields.

As far as duration of breast-feeding is concerned, it was found that the respondents in Robertson had in every instance breast-fed their babies for the longest period. No significant difference occurred between Swellendam (mass media guidance only) and Riversdale (control). Respondents in Robertson were also more inclined to breast-feed their babies, followed by Swellendam and lastly Riversdale. Although there were differences in the percentages of respondents who had breast-fed their babies in Robertson and Swellendam they were not as obvious as in the case of attitudes, knowledge and duration of breast-feeding.

These phenomena can probably be ascribed to the ability of guidance through a mass media programme to contribute largely in persuading women to breast-feed and to the fact that interpersonal inputs have a greater effect concerning improvement of knowledge and attitudes as well as motivation to breast-feed for a longer period. These findings suggest that the combined interpersonal and mass media guidance programme was more successful than the mass media programme alone.

\section{REFERENCES}

Brogan, B.D., Fox, H.M. 1984. Infant feeding practices of low- and middle-income families in Nebraska. Journal of the American Dietetic Association. 84(5).

Brostrom, K. 1981. Human milk and infant formulas: Nutritional and immunological characteristics. In: Suskind, M. (ed.) Textbook of Pediatric Nutrition. New York Raven Press.

Byerley, L.O., Kirksey, A. 1985. Effects of different levels of vitamin $C$ intake on the vitamin $\mathrm{C}$ concentration in human milk and the vitamin $\mathrm{C}$ intakes of breast-fed infants. The American Journal of Clinical Nutrition, 41.

Francis, D. 1986. Nutrition for children. Blackwell Scientific Publications: London.,

Glueck, C.J., Tsang, R.C. 1979. Pediatric nutrition: Potential relationship to the development of atherosclerosis. In: Winnick M. (ed.) Human Nutrition: Pre- and postnatal development. New York: Plenum Press.

Jelliffe, D.B., Jelliffe, E.F.P. 1979. Early infant nutrition: Breast-feeding. In: Winnick, $M$. (ed.) Human Nutrition: Pre- and post-natal development. New York: Plenum Press.

Murray, T.K. 1984. Nutrition research and public information. Journal of the Canadian Dietetic Association, 45(3).

Steyn, M. et al. 1987. 'n Ondersoek na die kennis, houdings en gebruike van 'n groep blanke moeders rakende borsvoeding en kindervoeding. Pretoria: Human Sciences Research Council.

Wharton, M. et al. 1982. Past achievements and future priorities - a view of present-day practice in infant feeding 1980. In: Turner, M.R. (ed.) Nutrition and Health. Lancaster: MTP Press Limited.

WHO Expert Committee Technical Report, Series 732. 1986. Community prevention of cardiovascular disease. WHO, Geneva.

Acknowledgements

The authors wish to acknowledge the contributions of

1. the staff of the Institute for Communication Research, the Institute for Statistical Research and the Bureau for Support Services of the Human Sciences Research Council,

2. the staff of the Department of Health Services and Welfare: Administration House of Assembly,

3. the staff of the Research Institute for Nutritional Diseases of the South African Medical Research Council

4. the Institute for Research Development of the Human Sciences Research Council for a grant enabling the first author to read this paper at the Sigma Theta Tau International 1989 Research Congress in Taiwan, R.O.C.

(Paper read at the Sigma Theta Tau International 1989 Research Congress Taipei, Taiwan, Republic of China)

Mariana Steyn, M.Soc. Sc. Nursing, RN,

RM, Dip. Paediatric Nursing, Dip. Clinica Care, Administration and Instruction, B. A. Honn (Soc.), Institute for

Communication Research, Human Sciences Research Council

Anne S.P. Swanepoel, M.Sc. (Dietetics), Sub-Directorate Nutrition,

Department of Health Services and Welfare: Administration House of Assembly, R.S.A.

Lesley J. Rossouw, B.Sc. Honn (Med.),

Formerly: Heart Foundation of Southern Africa

Marietjie L. Langenhoven, M.Sc. (Dietetics) Research Institute for Nutritional Diseases, South African Medical Research Council

P.L. Jooste, Ph.D., B.Sc. Honn (Clin. Epidemiology).

Research Institute for Nutritional Diseases South African Medical Research Council 